\title{
Extraction and quantitative estimation of nucleic acids and proteins from liver tissue of Heterpneustus fossilis (fish) and Caprine barbari (goat)
}

\author{
A.Pal*, V.K. Sharma** \& N. Khurana*** \\ *Assistant professor, Zoology Department, Holkar Science College, Indore \\ ** Professor, Zoology Department, Holkar Science College, Indore \\ ***Department of Biotechnology, Holkar Science College, Indore
}

\begin{abstract}
Heteropneustus fossilis (fish) and Caprine barbari (goat) for extraction and estimation of DNA, RNA and proteins. Nucleoproteins are soluble in solution of high ionic strength but insoluble in solution of low ionic strength. This property was used for extraction and estimation of DNA by diphenylamine. RNA was extracted by trichloroacetic acid and quantitative estimation was made using oriconol reagent. Total proteins were extracted and estimated by biuret method. DNA extracted was $0.42 \mathrm{mg}$, RNA $3.34 \mathrm{mg}$ and proteins $13.4 \mathrm{mg}$ from $2 \mathrm{gms}$ of liver tissue of Heteropneustes fossilis (fish) and from 2 gms of liver tissue of Caprine barbari (goat) DNA estimated was $0.57 \mathrm{mg}$, RNA 2.5mg and proteins were 12.4mg. It is seen that proteins estimated are more than DNA and RNA in given amont of tissue.
\end{abstract}

Key words: Nucleic acids, Proteins, Heteropneustes fossilis, Caprine barbari.

\section{Introduction}

The living cell is an extraordinarily complicated entity producing thousands of different macromolecules and harboring a genome. The methods of molecular biology depend upon an understanding of the properties of biological macromolecules. The systematic comparison of different animal genomics gives a chance of identifying genetic basis for diversity. We are fast entering a golden era of comparative genome analysis(Watson ,1953). Mice and humans contain roughly same number of genes about 28,000 protein coding genes A golden era of molecular biology was launched after it became possible to isolate specific DNA segments. Recently it became possible to apply molecular approach to analysis of nucleic acids and protein changes in gene expression causing morphological changes in different groups of animals. There is hope that analysis of DNA will illuminate the mechanisms of evolutionary diversity. Mackey et.al (1996) isolated DNA from liver tissue, muscles and plants. Iordi et al (1979) studied DNA component of chicken genome. Scinew et al (1990) studied mitotic chromosome complements and nuclear DNA content of four species of shrimps. Deoxyribonucleic acid is the genetic material and stores genetic information.. Eukaryotic cells contain many DNA molecules. Chromatin is a complex of DNA and histone. Nucleic acids are usually associated with proteins to form nucleoproteins. Sakagami (1991) reported high content of DNA protein in liver as compared to kidney, heart and wings. Zang et al (1990) isolated the protein from rat liver using alcohol precipitation and ultra filtration. Misky and Osawa(1991) isolated DNA from nuclei Konat et al (1996) gave a simple technique for the isolation of higher molecular weight genomic DNA from animal tissue and cell. Pal and Holkar (2013) gave that content of protein is higher than DNA and RNA in same amount of liver tissue of Clarias batrachus, Gallus domesticus and Rattus rattus. Proteomics is the science to determine which proteins are produced in a cell or tissue under a specific set of conditions, Devlin (2006). Goklen et al(1985) studied protein extraction. Gomez-Boustista (1986) studied level of total protein and protein fractions in the serum of rabbit.

\section{Material And Methods}

2 gms of liver tissue was collected from Heteropneustes fossilis and Caprine barbari for each experiment. Samples were collected from fresh animals and experiments for extraction and estimation were repeated ten times. Eight results from each group were taken into consideration. Nucleoproteins are soluble in solution of high ionic strength but is insoluble in solution of low ionic strength. This property was used for extraction and estimation of DNA by diphenylamine. Diphenylamine was prepared by dissolving one gram of diphenylamine in $100 \mathrm{ml}$ of glacial acetic acid and by adding $2.5 \mathrm{ml}$ concentrated sulphuric acid. RNA was extracted by trichloroacetic acid and quantitative estimation was made using orcinol reagent Total proteins were extracted and estimated by biuret method. 


\section{Results And Discussion}

Protein are the most abundant macro molecules in cells and constitute over half the dry weight of most organism. Genetic information is expressed by proteins. Each species of animal has a characteristic content of DNA. Eukaryotes vary greatly in DNA content and contain more DNA then prokaryotes. Lin,zang-ping et al. (1979) isolated DNA from plant materials. Misky and Osawa (1991) isolated DNA from nuclei which enabled various quantitative studies to be made. Sakagami et al (1991) in his study showed that mitochondrial DNA decreases in order of liver to testis to placenta. Litjerja (1980) determined the DNA content in the cerebellum of the rat in both male and female. Mackey et al (1996) isolated the DNA from tissue such as liver, muscles and plant. Shotwinska et al (1979) isolated DNA from liver of rats during hepatoma development. Shrinivasan (1988) described the effect of gamma radiation on rat tissue. Chetokov et al (1986) isolated phenylalanine hydroxylase from human liver. Bhattacharya et al (1990) made biochemical studies of liver of rats. Black and Johnson (1984) studied protein structure. Bart et.al(1985) in his studies showed that rat liver contained higher amount of RNA than DNA. More can be added to Molecular biology by studying more of deoxyribonucleic acid, ribonucleic acid and proteins. Zang et al (1990) extracted protein from rat liver.

Table 1:- DNA content in 2gms of liver tissue of Heteropneusteus fossilis(Fish) and Caprine barbari(Goat)

\begin{tabular}{|l|l|l|l|l|l|}
\hline S.no. & Class & Animal & Organ & Amount & Mean(mg) \\
\hline 1. & Pisces & Heteropneustes fossilis & Liver & $2 \mathrm{gms}$ & 0.42 \\
\hline 2. & Mammals & Caprine barbari & Liver & $2 \mathrm{gms}$ & 0.57 \\
\hline
\end{tabular}

Table 2:- RNA content from liver tissue of Heteropneustes fossilis(Fish) and Caprine barbari(Goat)

\begin{tabular}{|l|l|l|l|l|l|}
\hline S.no. & Class & Animal & Organ & Amount & Mean(mg) \\
\hline 1. & Pisces & Heteropneuste sfossilis & Liver & $2 \mathrm{gms}$ & 3.34 \\
\hline 2. & Mammals & Caprine barbari & Liver & $2 \mathrm{gms}$ & 2.5 \\
\hline
\end{tabular}

Table 3:- protein content in liver tissue of Heteropneustes fossilis(Fish) and Caprine barbari(Goat)

\begin{tabular}{|l|l|l|l|l|l|}
\hline S.no. & Class & Animal & Organ & Amount & Mean $(\mathrm{mg})$ \\
\hline 1. & Pisces & Heteropneustes fossilis & Liver & 2gms & 13.4 \\
\hline 2. & Mammals & Caprine barbari & Liver & 2gms & 12.4 \\
\hline
\end{tabular}

Table 4:- Mean values of DNA, RNA and proteins

\begin{tabular}{|l|l|l|l|l|l|l|l|}
\hline S.No & Animal & $\begin{array}{l}\text { Mean value DNA } \\
(\mathrm{mg})\end{array}$ & $\begin{array}{l}\text { Milligrams } \\
\text { percent (DNA) }\end{array}$ & $\begin{array}{l}\text { Mean value of } \\
\text { RNA(mg) }\end{array}$ & $\begin{array}{l}\text { Milligrams } \\
\text { percent (RNA) }\end{array}$ & $\begin{array}{l}\text { Mean protein } \\
\text { value (mg) }\end{array}$ & $\begin{array}{l}\text { Milligram } \\
\text { s percent } \\
\text { (proteins) }\end{array}$ \\
\hline 1. & $\begin{array}{l}\text { Heteropneust } \\
\text { es fossilis }\end{array}$ & 0.42 & 0.21 & 3.34 & 1.66 & 13.4 & 6.4 \\
\hline 2. & $\begin{array}{l}\text { Caprine } \\
\text { barbari }\end{array}$ & 0.57 & 0.28 & 2.5 & 1.25 & 12.4 & 6.35 \\
\hline
\end{tabular}

In the present study DNA is $0.42 \mathrm{mg}$, RNA is $3.34 \mathrm{mg}$ and proteins are protein are $13.4 \mathrm{mg}$ extracted and estimated from $2 \mathrm{gms}$ of liver tissue of Heteropneustes fossilis(Fish). In Caprine barbari(Goat) DNA is $0.57 \mathrm{mg}$, RNA is $2.5 \mathrm{mg}$ and proteins are $12.4 \mathrm{mg}$. extracted and estimated from $2 \mathrm{gms}$ of liver tissue. Thus it is seen that in same amount of tissue proteins are more than DNA and RNA. At the molecular level evolution is reflected in protein differences and large number of investigations are directed towards evaluating such differences and research in this area is moving rapidly.

\section{References}

[1]. Bart, R., Alexanian, D., Smith L. and Delasalle K.(1985) DNA and RNA content in multiple myeloma. Blood, 66(2):338-341

[2]. Bhattacharya A.,Sahu J. K., MajumdarG.andMaity C.R.(1990). Biochemical studies of liver of rats. J med Res. B 192 Oct. $374-377$.

[3]. Black, C.C.F. and Johnson, L.N.(1984). Protein structure. Trends Biochem. Sci. 9: 147-151.

[4]. Chetokov,V.V., Laptev A.V., Danilina E. and Shishkin S.S. (1986). Isolation of phenylalanine hydroxylase inactive protein from human liver. Inst. Med.Genet. Acad. Med. Sci USSR. Moscow USSR. Biokhimiya 51 (7) : 1210-1215. (In Russ with Russ and Engl. Summ.)

[5]. Devlin, T.M.(2006) Textbook of biochemistry with clinical correlation. A wiley medical publication. Jhonwiley and sons. New York/Chichester/Brisbane/Toranto/Singapore.p 26-72

[6]. Gomez-Boustista, M., Garcia, M.V. and Rojo-vazquez,F.A.(1986). The level of total protein and protein fractions in the serum of rabbit. Dep. Parasitol, Fac. Fram, UnivSolamanca, Spain. Annparasital Hum.Comp. 61(4) : 393-400

[7]. Goklen, K.E. and Nottan, T.(1985). Protein extraction using reverse micelles Cambridge, Mass. USA. Biotechnol. Prog 1(1) : 6974.

[8]. Irodi, C., Birgitta, M., Meunier-Rotival, Gabriet M. and Bernard G. (1979). The DNA component of the chicken genome. Lab Genetic Mol. Inst. Res. Bio. Mol. Univ. Paris VII, tour 43, 2 PI. Jussieu, F-75221 Paris. Eur J Biochem 99 (1) $179-186$.

[9]. Konat, G. Ganit,I. Laszkieveicz and Hagan, E.I. (1996). Rapid isolation of genomic DNA from animal tissue. Exp. Cell. Res. 190(2): 294-296. 
[10]. Lin, Zang-Pang,Liv, Hong,Jun, Wu,Shijan,MachengZaeu Yu-jinad Wang 1979 Isolation of DNA from plant materials.Acta Bot Sin 21(1):64-69.

[11]. Litjeria,M. (1980). The effect of neonatal androgenization on thymidine kinase activity and DNA content in the cerebellum of the rat. Neuroendocrinol Res. Lab. 151 B. veterans Adm. Med. Cent. North Chicago, III 60064, USA. Brain Res. 181 (2) : $401-412$.

[12]. Mackey,K., Seim, W.P. and Chomczyski,P. (1996). The use of DNAzol ® for the rapid isolation of genomic DNA from whole blood. Biomedical Product Supplement, 13-15.

[13]. Misky and Osawa (1991)The interphase nucleus. Academic press, New York, 677-770

[14]. Pal,A. and Holkar S (2013) Extraction and quantitative estimation of nucleic acids and proteins from liver tissue of Clarias batrachus, Gallus domesticus and Rattus rattus. Adv. pharmacol. Toxicol 14(2) 43-47.

[15]. Sakagami, M., Kazue, Suzuki I., Ikuko, S. and Harutak, M. (1991). Preparation and RFLP analysis of Mitochondrial DNA from preserved pig organs. Cent technology Dev. Health science Res. Inst. Yokanawashi-240 Anim sci. Technol 62(2): 125-135.

[16]. Scinew, C. ,Daugherty, W.J. and Sanditer P.A. (1990). Mitotic chromosome complements and nuclear DNA content of four species of shrimps of the genus penaeus. Rosenstiel Sch. Marine Atmospheric Sci, 4600 Ricken backer causeway. Miami Fla 33149. J Crustacean Bio 10 (1) : 29-36.

[17]. Shotwinska-palugniok,E. and Willzok, T.(1979). Chromatographic pattern of DNA isolated from liver tissue during hepatoma development. Inst. Med. Chem. Phy. Univ. Med. Sch. Silesia, 41-2000 Sosowiec, Pol. Neoplasma 26 (4): 461-470.

[18]. Shrinivasan, M.N. and Basu, S.K. (1988). The altered DNA content in rat tissue following whole body gamma radiation. Radiant biochemistry, Div. Inst. Nucl. Med. Allied Sci. Lucknow Rd. Delhi. 11007, India. Radiobiol. 29 (4) : $421-427$.

[19]. Watson,J.D. and Crick, F.C. (1953). Molecular structure of nucleic acids. A structure for deoxyribose nucleic acids. J. Nature (171), 737-738. Academic press, New York.

[20]. Zang, C., Jionghua, L., Jihong, Z., Yundi, G. and Lingzhong, C.(1990). Protein extracted from rat liver. Dep. Histol. Fac Basic Med. Sci. shanghai Med. Univ., Shanghai, China ActaAcad Med. Shanghai 17 (3) : 194-196 (In chin. With chin. Engl. Sum.) 